Cordova Jurnal

ISSN (P) 2302-3155,

(e) 2714-5808

Vol. 9, No. 12019

\title{
THE ENGLISH AND SASAK DERIVATIONAL MORPHEME ON STUDY COMPARATION
}

\author{
Sugianto ${ }^{1}$, Kamarudin², Muhamad Sarifuddin ${ }^{3}$ \\ Mandalika University Of Education \\ Faculty Of Education For Language And Art \\ sugianto@ikipmataram.ac.id ${ }^{1}$, kamarudin.ntbe@gmail.com² \\ muhammadsarifuddin@gmail.com ${ }^{3}$
}

The researcher is aimed at comparing the derivational morphemes exist in sasak language and English language. This comparison leads into the construction of new words variation to build a complete sentence bot in English and in Sasaknese. By comparing the derivational morphemes between Sasak language and English language, some similarities and differences of both languages truly revealed. The similarities between them brought the easiness to the students of Sasak while learning English. Conversely, the differences caused difficulties the students who are learning English. The comparison between these two languages derivational morphemes hopefully brought some positive effects on students' English mastery particularly the mastery of vocabularies and the process that made them up. An in-depth study on how those derivational morphemes in both languages are different were conducted for the sake of the data complete of the study. The interview section of the research was conducted among the experts of those two languages to support the filed data needed in the research. The data collected through the interview process istranscribed and reduced based on research need for the sake of answering the research question. The research conclusion said that some derivational morphemes exited in the Sasak were also found in English derivational morpheme process which then translated into some easiness can be found during English study process of the students who speak Sasak as their first language.

Keywords: Sasak, English, Derivational Morpheme 


\section{Cordova Jurnal}

ISSN (P) 2302-3155,

(e) 2714-5808

Vol. 9, No. 12019
Jurnal kajian Bahasa dan Budaya terbit 2 kali setahun oleh UPT. Pusat Pengembangan Bahasa (P2B) UIN Mataram. Tersedia online pada https://journal.uinmataram.ac.id/index.php/cordova

\section{INTRODUCTION}

Starting the article over, the question "Why do English language become that important international language?" was asked, and one of the possible answer is that English is the most dominant language which is spoken by almost all countries all over the world, even English called as the international language for its role to connecting the people who use different languages. "English is one of the international languages all over the world. Prediction of English speaker in 1920 is about 170 million people" (Bloomfield, 1995:11) stated based on the statement above we can predict that nowadays must be over 170 million people speak English.

The above phenomena show that English has been spoken by almost all people in every country. In the other side English also used as a medium of conveying knowledge, as the proof lets we have a look in to the libraries, there are a lot of books are written in English, the research are written in English, some science also written in English, even all product in our environment also written in English. Thus, English is completely needed for learning various kind of 


\section{Cordova Jurnal}

ISSN (P) 2302-3155,

(e) 2714-5808

Vol. 9, No. 12019
Jurnal kajian Bahasa dan Budaya terbit 2 kali setahun oleh UPT. Pusat Pengembangan Bahasa (P2B) UIN Mataram. Tersedia online pada https://journal.uinmataram.ac.id/index.php/cordova

knowledge such as science, history, culture, politics and economy.

What about English in Indonesia? In Indonesia, English is considered as the most important foreign language taught at almost all levels of school. It has been studied as a compulsory subject at elementary school, junior high school, senior high school, up to university; even English has become one of the three subjects that should be passed by all students in national examination. This fact proved that English has played a very important role among the education in Indonesia.

Without vocabularyit is impossible for the students to be able to speak any sentence. Vocabulary is not only needed in listening and speaking but also needed in reading English text. Reading without mastering vocabulary used in the text is the same with reading without knowing what you read for, because you cannot grasp what messages actually deliver in the text. That also happen in speaking and listening, you cannot grasp the messages deliver by someone through his/her speech till you know the vocabularies have just said by the speakers (Harmer, 1998:68). 


\section{Cordova Jurnal}

ISSN (P) 2302-3155,

(e) 2714-5808

Vol. 9, No. 12019
Jurnal kajian Bahasa dan Budaya terbit 2 kali setahun oleh UPT. Pusat Pengembangan Bahasa (P2B) UIN Mataram. Tersedia online pada https://journal.uinmataram.ac.id/index.php/cordova

In relation to the language teaching matter, teachers also have to provide and select the most appropriate method in teaching their students. However, almost every English teacher admitted that it is not an easy job to do since teaching English as a foreign language still faces a lot of problems. Those problems found commonly come from the teaching and learning process which involve problem in method of instruction, teaching media, materials and method of teaching or teaching strategy.

Knowing that there are so many problem faced both by the teacher and students Sasak in earning English, the researchers are now insisting to dig up more information through the research to provide as much as possible information about the language source (Sasak language) and target language (English language) which put the research on languages comparison is urgently needed. One of endeavors made through the research which is aimed at enriching the learning material of English and even to compare between students' mother tongue and target language being learned for the sake of English material rematch with the source language mastered by the students. 


\section{Cordova Jurnal}

ISSN (P) 2302-3155,

(e) 2714-5808

Vol. 9, No. 12019
Jurnal kajian Bahasa dan Budaya terbit 2 kali setahun oleh UPT. Pusat Pengembangan Bahasa (P2B) UIN Mataram. Tersedia online pada https://journal.uinmataram.ac.id/index.php/cordova

In accordance with the above explanation, the research question was then asked "is there any differences of the derivational process to construct a new word in Sasak language compared to English language does?" (2) "are there any similarities of the derivational process to construct a new word in Sasak language compared to English language does?" Which was aimed at finding out whether or not there is any similarities of the derivational process to construct a new word in Sasak language compared to English language does.

Through this research, significances contribute to some like teachers and language instructorsdealing with the information about the derivational morphemes in Sasaknese that hopefully contributes much on helping them in aiding the teaching of English.

\section{REVIEW OF LITERATURE}

Sasak language is spoken primary by Sasak technique "dengan Sasak"or Sasak speakers' who 


\section{Cordova Jurnal}

ISSN (P) 2302-3155,

(e) 2714-5808

Vol. 9, No. 12019
Jurnal kajian Bahasa dan Budaya terbit 2 kali setahun oleh UPT. Pusat Pengembangan Bahasa (P2B) UIN Mataram. Tersedia online pada https://journal.uinmataram.ac.id/index.php/cordova

majority lived in Lombok Island and used as the "mother language" the first language in daily conversation, and commonly grouped into "bahase alus" and "bahase biase" where bahase alus is the property of the "menak" noble group which has lexical differentiation for the high style, and bahase biase refers to ordinary group

Sasak language has various kinds of dialect that sometimes intelligible between others dialect. Based on the data, sasak language divided into seven dialects, Kuto-Kute (Around Bayan, and North Sasak), Ngeto-Ngete (Around Suralaga and Sembalun), MenoMene (Around Praya, Central Sasak), Ngeno-Ngene (Central east to north coast, and Central West coast 


\section{Cordova Jurnal}

ISSN (P) 2302-3155,

(e) 2714-5808

Vol. 9, No. 12019
Jurnal kajian Bahasa dan Budaya terbit 2 kali setahun oleh UPT. Pusat Pengembangan Bahasa (P2B) UIN Mataram. Tersedia online pada

https://journal.uinmataram.ac.id/index.php/cordova

Sasak), Mriak-Mriku (Central South Sasak around

Bonjeruk, Sengkol, and Pujut), Menu-Meni (Central, and Shout East Sasak), Menung-Mening (Central East Sasak). These indicated that the term "Sasak" always refers to regional variation.

\section{Affixation}

The Affixation is the morphological process in which bound morphemes are attached to a root or stems to mark changes in meaning, part of speech, or grammatical relationships. Affixation falls in the scope of Morphology where bound morphemes are either roots or affixes (Nida 1949). 


\section{Cordova Jurnal}

ISSN (P) 2302-3155,

(e) 2714-5808

Vol. 9, No. 12019
Jurnal kajian Bahasa dan Budaya terbit 2 kali setahun oleh UPT. Pusat Pengembangan Bahasa (P2B) UIN Mataram. Tersedia online pada https://journal.uinmataram.ac.id/index.php/cordova

Frank (1972: 121) describes the formation of adjectives in the English language into two major groups, namely adjectives are formed by nouns and adjectives are formed by the verb. In contrast to Frank, plague (2003: 94) describes several types of adjectiveforming affixes attached to nouns, verbs, and forms the root bound.

\section{Derivation}

Derivation is the process adding derivational morphemes which change word category, part of speech and the meaning of previous word. In Sasak Language this term is really productive in fact we can mention many examples of derivational morphemes, to make it evidence lets compare these examples Changing Noun become adjective, Kepeng "money" become bekepeng "rich"

Changing noun become verb Lagu "song" becomebelegu "singing" From these two examples we 


\section{Cordova Jurnal}

ISSN (P) 2302-3155,

(e) 2714-5808

Vol. 9, No. 12019
Jurnal kajian Bahasa dan Budaya terbit 2 kali setahun oleh UPT. Pusat Pengembangan Bahasa (P2B) UIN Mataram. Tersedia online pada https://journal.uinmataram.ac.id/index.php/cordova

can conclude that by adding the derivational morphemes such "be" may change the meaning and category of the previous words, and also indicated that the Sasak Language has morphological process in it.

\section{RESEARCH METHOD}

The research method used in this study is comparative research. This research kind simply compares two or more things with a view to discover something between two things being compared. This kind of research design often be used to study a multiple discipline in one study. Comparative research can take many forms depending onthe two key factors, those are space and time. The historical comparative research involves comparison between time and frames. The two main choices within this model are comparing two stages in time can be snapshots or time-series, or just comparing the same thing over time, to see if a particular treatment has any effects over a stretch of time. 


\section{Cordova Jurnal}

ISSN (P) 2302-3155,

(e) 2714-5808

Vol. 9, No. 12019
Jurnal kajian Bahasa dan Budaya terbit 2 kali setahun oleh UPT. Pusat Pengembangan Bahasa (P2B) UIN Mataram. Tersedia online pada https://journal.uinmataram.ac.id/index.php/cordova

Setting of the research was conducted on Pejanggik dialect as the main sources of Sasak Menu-Meni dialect in which about $90 \%$ of the locals are speaking the Menu-Meni dialect sasak. Sounds very interesting to get in touch with the locals with puresasak language mastery with their special features.

Pejanggik dialects are quite unique compare to any other dialects like Bayan, or Selaparang in which Bayan tend to be less understood by other dialects in Lombok even the dialects are still at one steam. Meanwhile the Selaparang dialect dominate the eastern part of Lombok and the rest are spoken by the western part of Lombok lining from Ampenan Coast to the north. Pejanggik its self dominate the central part of Lombok lining to the south east across Jerowaru to Keruak. These dialects divisions are remain unique of the modern influence comes from rapid urban.

The research object of the study is Sasaknese or sasak language Menu Meni dialect in particular. Sasak language is one of the local languages spoken among Sasak people in Lombok. It is used as a means of communication by the Sasak ethnic group, inhabiting Lombok island which make up the majority of the 


\section{Cordova Jurnal}

ISSN (P) 2302-3155,

(e) 2714-5808

Vol. 9, No. 12019
Jurnal kajian Bahasa dan Budaya terbit 2 kali setahun oleh UPT. Pusat Pengembangan Bahasa (P2B) UIN Mataram. Tersedia online pada https://journal.uinmataram.ac.id/index.php/cordova

population of Lombok. Sasak language is the first native language after Indonesian, used by most group of people in lombok island in their daily communication.

Sasak language has various dialects, in which every dialect is spoken according to three main caste or context of speaking. Those three contexts are Soft language or noble language is the language used by a group of nobles, The Madya language or intermediate language is a language that has been entered by soft language, used by middle class, Ordinary language is the language used by the group or the general public rows of coral.

The researcher used interview sheet as the instrument. The interview sheet guided the researcher in interviewing the research participants, giving the information of what should and what should not to be collected in the research, meaning that the data related.

Analyzing the data in this study, the researcher used description of the data in which the researcher interviewed the sources of information, research participants in this case, which then followed by transcribing the interview data results, reducing the 
Cordova Jurnal

ISSN (P) 2302-3155,

(e) 2714-5808

Vol. 9, No. 12019
Jurnal kajian Bahasa dan Budaya terbit 2 kali setahun oleh UPT. Pusat Pengembangan Bahasa (P2B) UIN Mataram. Tersedia online pada https://journal.uinmataram.ac.id/index.php/cordova

data needed. The last step of analyzing data process in taking conclusion on the affixation found in Sasak language and its meaning at the same time. Comparison with the English affixation is needed before using it into real classroom teaching practice.

\section{FINDING}

The study on Sasak derivational morphemes leads into the word formation patterns that the researcher found in the data. A word can be used as a basis for the formation of other words with certain rules. In this case, the formation of verbs derivative are formed through other types of word classes. In its distribution, the formation of verbs derivative can be formed through verbs, nouns, and adjectives. Even the derivational process also found in vice versa.

Conversely, in Sasak language there are three types of affix that found which can be used to form derivative verb. The types of affixes are prefix, 
Cordova Jurnal

ISSN (P) 2302-3155,

(e) 2714-5808

Vol. 9, No. 12019
Jurnal kajian Bahasa dan Budaya terbit 2 kali setahun oleh UPT. Pusat Pengembangan Bahasa (P2B) UIN Mataram. Tersedia online pada

https://journal.uinmataram.ac.id/index.php/cordova

simulfix, and suffix. Those affixes are described through the examples of the word's formation in Sasak language. The descriptions are found the table 0.1 below.

\section{Tabel 01 \\ The affixes to preform verbs}

\begin{tabular}{|c|c|c|}
\hline Prefix & Suffix & Simulfix \\
\hline$t e-$ & $-a \eta$ & te $-a n$ \\
\hline$p e-$ & & \\
\hline$b e-$ & & \\
\hline$m e-$ & & \\
\hline
\end{tabular}

Affixes are the attachment of words-elements into the steam of words to perform new meanings or new words classes. The first affix that attached at the beginning of a word or prefix that can form verbs in Sasak language is prefixte-. The function of prefix te- in

Copyright (C) 2019 by Cordova Journal. This work is licensed under (CC-BY-NC-ND) 


\section{Cordova Jurnal}

ISSN (P) 2302-3155,

(e) 2714-5808

Vol. 9, No. 12019
Jurnal kajian Bahasa dan Budaya terbit 2 kali setahun oleh UPT. Pusat Pengembangan Bahasa (P2B) UIN Mataram. Tersedia online pada https://journal.uinmataram.ac.id/index.php/cordova

Sasak is to form "passive voice" or to make the verb become passive. Examples can be found in words "palang" into "tepalang" or "paling" into "tepaling" which mean "steal" into "stolen"

The second affix that attached at the beginning of a word or prefix that can form verbs in Sasak language is prefix pe-. The function of prefix te- in Sasak is to form the meaning "to cause something become". Take a look at the affixation process of verb with the following prefix. The example of words derived from prefix "pe-," are "tukah" into "penukah", "kuat" into "pekuat" which mean "strong" into "strengthen"

The next form of affix that attached at the beginning of a word or prefix that can form verbs in Sasak language is prefix be-. The function of prefix be- in Sasak is to form the verb become intransitive verb, which means if the verb is used in a sentence, the verb does not need an object. Take a look at the affixation process of verb with the following prefix. Example of 


\section{Cordova Jurnal}

ISSN (P) 2302-3155,

(e) 2714-5808

Vol. 9, No. 12019
Jurnal kajian Bahasa dan Budaya terbit 2 kali setahun oleh UPT. Pusat Pengembangan Bahasa (P2B) UIN Mataram. Tersedia online pada https://journal.uinmataram.ac.id/index.php/cordova

words are like "gawe" into "begawe" or "regaq" into "beregaq" that means "bargain" into "bargaining"

The next affix that attached at the beginning of a word or prefix that can form verbs in Sasak language is prefixme-. The function of prefix me- in Sasak is to tell about prent action. Take a look at the affixation process of verb with the following prefix. The examples of words are "mongkaq" into "memongkaq" which means "cook" into "cooking"

And then the last is sufix and the only affix that attached at the end of a word or suffix that can form

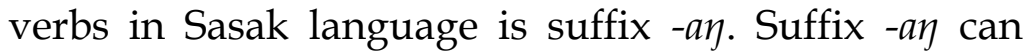
form the meaning of "causing" and also this suffix has another function to form benefactive verbs. That is, the work or activity intended by the verb is done for someone else not for the role of the subject or agent. The examples of words are "piaq" into "piaqan" which means "make" into "made" 


\section{Cordova Jurnal}

ISSN (P) 2302-3155,

(e) 2714-5808

Vol. 9, No. 12019
Jurnal kajian Bahasa dan Budaya terbit 2 kali setahun oleh UPT. Pusat Pengembangan Bahasa (P2B) UIN Mataram. Tersedia online pada

https://journal.uinmataram.ac.id/index.php/cordova

The first and the only affix that attached at the beginning and at the end of a word or simulfix that can form verbs in Sasak language is suffix simulfixte an. The function of simulfixte-an in Sasak is to form "passive voice" or to make the verb become passive. The examples of words are "jauq" into "tejauqan" or taeq into "tetaeqan" which mean "getting up" into "get something up"

\section{CONCLUSION}

The research finding of the study says that there is some significant similarities of both languages Sasak and English that is reflected through how the words are perform in affixation.The result of the study shows that both Sasak and English undergo word-formation process through derivational process in which it is said that both Sasak and English have derivationalprocess to perform a new word. 


\section{Cordova Jurnal}

ISSN (P) 2302-3155,

(e) 2714-5808

Vol. 9, No. 12019
Jurnal kajian Bahasa dan Budaya terbit 2 kali setahun oleh UPT. Pusat Pengembangan Bahasa (P2B) UIN Mataram. Tersedia online pada

https://journal.uinmataram.ac.id/index.php/cordova

In terms of differences of derivational process between Sasak and English language, there are some differences between both of them where English language does not have simulfix like in Sasak language". The prefix and suffix are not similar both in Sasak and English language. Sasakhas only one suffix while English has four suffixes. Mostly, English suffix can be attached to the word class adjective and noun except for suffix /-ate/ which has special circumstances where this suffix is attached to the bound morpheme.

In relation to derivational process happened in both languages, Sasak suffix is able to be attached to almost all word classes except adverb because this suffix is the most productive suffix in Sasak. This suffix can be attached to noun, adjective, verb, and adverb.

In terms of meaning of affix in both Sasak and English language. Most of them are different except 
Cordova Jurnal ISSN (P) 2302-3155,

(e) 2714-5808

Vol. 9, No. 12019
Jurnal kajian Bahasa dan Budaya terbit 2 kali setahun oleh UPT. Pusat Pengembangan Bahasa (P2B) UIN Mataram. Tersedia online pada

https://journal.uinmataram.ac.id/index.php/cordova

for prefix / pe-/ in Sasak and prefix /en-/ in English.

The function of prefix /te-/ in Kuto-Kute dialect is to form a passive verb or passive voice. 


\section{Cordova Jurnal}

ISSN (P) 2302-3155,

(e) 2714-5808

Vol. 9, No. 12019
Jurnal kajian Bahasa dan Budaya terbit 2 kali setahun oleh UPT. Pusat Pengembangan Bahasa (P2B) UIN Mataram. Tersedia online pada https://journal.uinmataram.ac.id/index.php/cordova

\section{REFERENCE}

Brown, H.D. (2003). Language Assessment: Principles and Classroom Practice. San Francisco. Longman.

Creswell, J.W (2008). Educational Research; Planning, Conducting, And Evaluating Quantitative and Qualitative Research. Boston. Pearson international edition.

DepartemenPendidikanNasional. (2003) Kurikulum 2004: $\quad$ StandarKompetensi Mata PelajaranBahasaInggrisSekolahMenengahAtasd an Madrasah Aliyah. Jakarta: DepartemenPendidikanNasional.

Hadijah, S. (2010). A Study on Passivization in Sasak "Meriak-Meriku" Dialect: a Case Study at Batu-Tulis Village of Central LombokMataram: English Department of mataram institute of teacher training unpublished thesis.

Mahyuni. (2006). Speech Styles and Cultural Consciousness in Sasak Community.Mataram: YayasanCerdas 


\section{Cordova Jurnal}

ISSN (P) 2302-3155,

(e) 2714-5808

Vol. 9, No. 12019
Jurnal kajian Bahasa dan Budaya terbit 2 kali setahun oleh UPT. Pusat Pengembangan Bahasa (P2B) UIN Mataram. Tersedia online pada

https://journal.uinmataram.ac.id/index.php/cordova

Ratna Yulida Ashriany. (2008). Sistem Verba Bahasa Sasak Dialek Bayan Dari DasarVerba Dan Nomina.Thesis. Universitas 11 Maret Surakarta.

Raja, P. (2012) The Language of an Indonesian Child Named Mika in the Telegraphic and Simple Sentence Stages. Unpublished doctoral dissertation. Malang: UniversitasNegri Malang.

Suryati, N. (2005) Teaching Various Monologue Texts. A paper presented in One-Day Workshop on Making the Most of Various Monologue Texts in the Teaching of English. Malang. State University of Malang. 